\title{
Examining Alopecia through Selected Case Studies in Bangladesh
}

\author{
Zahed Parvez Barbhuiyan and Samina Akter
}

\section{ABSTRACT}

The COVID-19 pandemic has been triggered unprecedented health crisis across the globe. Millions have lost their lives to the virus while many are still coping with post-covid complications. Much of the health impacts are still unknown. The horror unleashed by the virus has been a major source of stress for many people. Indeed, this situation is a difficult process for the individuals to cope up with and this resulting in psychosocial stress. This increased psychosocial stress can affect the individuals suffering from stress sensitive skin diseases. Most of the people notice heavy hair fall during quarantine. We also observed increasing cases of alopecia in our clinic for last several months among those who have recovered from COVID-19. The pandemic has been spreading in Bangladesh since March 2020 and numerous methods were taken including quarantine in order to prevent the spreading of the disease that were at the highest point in May 2020. Thus, we noticed the percentage of the patients with alopecia in 2020 is higher compared to the corresponding period of previous year.

Keywords: Alopecia, COVID-19, Hair fall, Stress.

\section{INTRODUCTION}

SARS-CoV-2 may be mild in most of the cases but for few it has devastating consequences, starting from tissue hyper inflammation, fibrosis and scaring of lungs, lung collapse multi organ failure even death [1]. This study is conducted among the patients who suffered from covid 19. Many of them later develop heavy hair fall.

\section{METHODS}

This study was conducted collecting data from the patients who recovered from COVID-19 and came to visit our institution after facing heavy hair fall. Sociodemographic characteristics of all participants such as age, sex, occupation was recoded. All the participants were asked questions about pre and post COVID-19 pattern of hair loss. Participants with complaints were asked what they do as a remedy.

\section{CASE REPORT}

\section{A. Case 1}

A 33 year old service holder came to us after 14 days of covid 19 recovery with complaints severe hair fall. He had no hormonal issues, DM, or Hypertension. He was given
Submitted : March 29, 2021

Published : April 29, 2021

ISSN: $2593-8339$

DOI: $10.24018 /$ ejmed.2021.3.2.791

Dr. Zahed Parvez Barbhuiyan MBBS (DU), BCS (Health), MPH (BSMMU), DDV (DU),

Trained in Cosmetic \& Hair Transplant Surgery (India),

Consultant \& Cosmetic Surgeon,

Assistant Professor, Shaheed Suhrawardy Medical College \& Hospital, Dhaka, Bangladesh.

(e-mail: zahedparvezmmc@ gmail.com)

Dr. Samina Akter*

Medical Officer, Dr. Zahed's Hair \&

Skinic, Panthapath, Dhaka,

Bangladesh.

(email: samina.mithila123@gmail.com)

*Corresponding Author
Minoxidil spray and vitamin supplementation and followed up after two months. Within two months there was improvement.

\section{B. Case 2}

A 23 year old student came to us after 2 months of covid 19 recovery with complaints hair fall. He had no hormonal issues, DM or Hypertension. He was also given Minoxidil spray, Vitamin supplementation as well as PRP therapy. He was followed up after two months. These reduced hair falls.

C. Case 3

A 28 year old housewife came to us after 4 months of covid 19 recovery with complaints of heavy hair fall. She had hypothyroidism. She used Minoxidil spray for two months but there was no improvement. Hence, we started PRP therapy and after six sessions she felt improvement.

\section{Case 4}

A 30 year old housewife came to us after 3 months of covid 19 recovery with complaints of heavy dandruff and hair fall. She had no hormonal issues or any other illness. She took some kind of homeopathic medicine ingredient of which was unknown. She was prescribed Minoxidil spray, Vitamin D and PRP therapy. After two months but there was improvement. 


\section{E. Case 5}

A 38 year old businessman came to us after 5 months of covid 19 recovery with complaints severe hair fall. He was hypertensive for last 3 years. He was given Minoxidil spray and vitamin supplementation and followed up after two months. Within two months there was improvement.

\begin{tabular}{cccccc}
\hline \multicolumn{7}{c}{ TABLE I: SUMMARY OF CASES } \\
Patient no. & Age & Sex & $\begin{array}{c}\text { Associated } \\
\text { medical condition }\end{array}$ & $\begin{array}{c}\text { Positive COVID 19 } \\
\text { testing via }\end{array}$ & $\begin{array}{c}\text { Duration of } \\
\text { hospitalization for } \\
\text { COVID-19 }\end{array}$ \\
\hline 1 & 33 & Male & No & RT PCR & No \\
2 & 23 & Male & No & RT PCR & No \\
3 & 28 & Female & Hypothyroidism & RT PCR & No \\
4 & 30 & Female & No & RT PCR & No \\
5 & 38 & Male & Hypertension & RT PCR & \\
\hline \hline
\end{tabular}

\section{DISCUSSION}

Fever is one of the symptoms of covid 19. Fever can cause hair shedding during and after covid 19 [2]. Vitamin D deficiency is one of the suspected causes of hair loss after COVID-19 [3]. Stress can also be responsible for temporary hair shedding [4]. COVID-19 definitely causes more anxiety and stress. All these together $r$ resulting in hair shedding which is usually improved within three to six months.

\section{CONCLUSION}

We acknowledge the limitations of these case reports and recognize that additional studies are required to determine the actual effect of COVID-19 on hair and its causes.

\section{REFERENCES}

[1] Li YC, Bai WZ, Hashikawa T. The neuroinvasive potential of SARS $\mathrm{CoV} 2$ may play a role in the respiratory failure of COVID 19 patients. Journal of medical virology. 2020 Jun;92(6):552-5.

[2] Zhu N, Zhang D, Wang W, Li X, Yang B, Song J, Zhao X, Huang B, Shi W, Lu R, Niu P, Zhan F, Ma X, Wang D, Xu W, Wu G, Gao GF, Tan W, China Novel Coronavirus Investigating and Research Team (2020) A novel coronavirus from patients with pneumonia in China, 2019. N Engl J Med 382:727-733.

[3] Rudnicka L, Gupta M, Kassir M, et al. Priorities for global health community in COVID-19 pandemic. Dermatol Ther. 2020; e13361. https://doi.org/10.1111/dth.13361 [published online ahead of print, 2020 Apr 1]. Wiley Online Library PubMed Web of Science®Google Scholar.

[4] World Health Organization Emergency Dashboard. Coronavirus Disease 2019 (COVID-19). World Health Organization. 2020 https://experience.arcgis.com/experience/685d0ace521648f8a5beeee 1b9125cd. Accessed April 6, 2020.

[5] Turkish Republic Ministry of Health. New Coronavirus Disease (COVID-19). Turkish Republic Ministry of Health. 2020. https://covid19bilgi.saglik.gov.tr/tr. Accessed April 7, 2020.

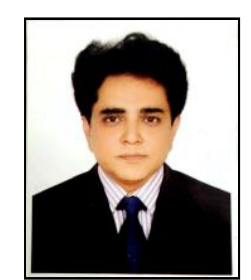

Dr. Zahed Parvez Barbhuivan is a renowned Professor of Shaheed Suhrawardy Medical College \& Hospital, Dhaka, Bangladesh. He is the pioneer of Hair Transplantation Surgery in Bangladesh. He completed his MBBS degree from Mymensingh Medical College, Bangladesh.

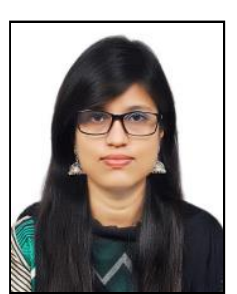

Dr. Samina Akter is currently working as a Medical Officer at Dr. Zahed's Hair \& Skinic, Panthapath, Dhaka, Bangladesh. Her research focus is in the area of public health, contagious diseases, etc. She holds an MBBS degree from Kumudini Women's Medical College, Tangail, Bangladesh. 